\title{
My Padrino
}

\section{Xuan Carlos Espinoza-Cuellar}

Abstract A cherished Santero father figure, the author's padrino (godfather), brings hope and healing into his life.

My godfather is an organic intellectual

With endless remedies for heartache

His best remedy so far is his embrace

And when he says to me "my son, everything will be alright"

My godfather is an organic intellectual

He knows hundreds and hundreds of sacred plants

He sings to them, summons their energies

He says to me "la primera alabanza es el canto" (the first form of worship is song)

My godfather is an organic intellectual

His mind is filled with eternal sacred chants

I bow down, forehead to the floor

I salute him, "dide" (rise up) he says, and lifts my soul

X. C. Espinoza-Cuellar $(\bowtie)$

University of Nevada Las Vegas, Las Vegas, NV, USA

(C) The Author(s), under exclusive license to Springer Nature Switzerland AG 2021

A. R. Del Castillo, G. Güido (eds.), Fathers, Fathering, and

Fatherhood, Palgrave Studies in Literary Anthropology, https://doi.org/10.1007/978-3-030-60877-4_28 